\title{
Effect of Different Disinfection Methods on Quality of Tap Water ${ }^{2}$
}

\begin{abstract}
This paper specifies the effect of using strong oxidants in water treatment technologies on the formation of disinfection by-products. The study was developed by collecting water samples from four water treatment plants of the Municipal Water and Sewerage Company (MPWiK) in Krakow and at selected sampling points within the water supply networks. The analysis was comprised of selected indicators of water quality after the treatment process during the years of 2011-2017. From the carried-out investigation, it was concluded that the concentration of free chlorine in the water supply network concurrently decreased with increases in the distance from the treatment plant. This dependence was found in 19 out of 28 water supply points. While analyzing the annual average concentrations of free chlorine in the municipal water, it was noted that the highest values at the study points occurred in 2011. During the other years, decreases in this indicator were observed. This follows from the analysis that the water disinfection by-products did not exceed permissible limits.
\end{abstract}

Keywords: water disinfection, water quality, drinking water, water supply network

Received: 11 July 2018; accepted: 24 June 2019

\footnotetext{
1 Krakow University of Economics, Faculty of Commodity Science and Product Management, Chair of Product Technology and Ecology, Krakow, Poland e-mail: artur.jachimowski@uek.krakow.pl ORCID ID: https://orcid.org/0000-0003-4045-2418

2 The paper was financed with funds earmarked for the statutory activity and funds provided to the Faculty of Commodity Science of the Krakow University of Economics by the Ministry of Science and Higher Education for research by young scientists and participants of doctoral studies
} 


\section{Introduction}

The main factor that determines the effectiveness of water disinfection is its degree of contamination [1]. On the other hand, ensuring the bacteriological safety of water is one of the main purposes of the treatment. In currently used treatment technologies, the microbiological purity of water is ensured through disinfection - the task of which is to remove, destroy, or inactivate any forms of pathogenic organisms. This helps prevent the spread of many infectious diseases. The microbiological purity of water is also essential due to the possibility of its recontamination in the water supply network. The disinfection of water is the last stage of the treatment process, and it can be achieved by applying some physical and chemical methods [2, 3-6].

The application of strong oxidants like chlorine, chlorine dioxide, and ozone cause the formation of disinfection by-products [7-9]. These by-products considerably affect the sanitary assessment of the municipal water supply [10]; they also make up a group of undesirable substances - the majority of which are organic compounds that result from the reaction between the disinfectant with organic pollutants in water. This results in oxidation products of the inorganic components in the form of bromates(V), chlorates(III), and chlorates(V) [11].

The aim of this paper is to determine the effect of applying strong oxidants in water treatment technology and their effects on the formation of disinfection by-products. The study was developed by collecting water samples from four water treatment plants of the Municipal Water and Sewerage Company in Krakow and at selected sampling points within the water supply network corresponding to those plants.

\section{Characteristics of Selected Methods of Water Disinfection}

The methods of water disinfection include heating, ultraviolet (UV) radiation, ultrasonic treatment, and ultrafiltration. The physical disinfection techniques currently applied in the water treatment technology are restricted to ultraviolet radiation as a bactericidal agent [6].

The use of ultraviolet radiation is a disinfection method that does not change the taste, smell, or physicochemical composition of the water. UV light is a part of electromagnetic radiation with a wavelength of $100-400 \mathrm{~nm}$. Within a range of 200-280 nm, it has a bactericidal effect on microorganisms, destroying their DNA structure; if the appropriate absorption time and intensity of UV radiation are used, microorganisms can be completely destroyed. The efficiency of UV radiation depends on the color and turbidity of the water to be disinfected. The effect of UV disinfection can be attenuated in the presence of suspensions and colloidal particles. These can absorb some amounts of radiation. In this method, no by-products are formed as a result of reactions with organic matter. On the other hand, the lack of any remains of a disinfectant in the water may promote recontamination 
in the distribution network. For this reason, this technique should be applied in combination with chlorination, chloramination, or with disinfection by means of chlorine dioxide $[2,3,5,6,12,13]$.

Chemical disinfection consists of introducing chemical substances that destroy microorganisms in the water. The effectiveness of the chemical agent depends on the concentration of the bacterial strains living in the water, the duration of microorganism contact with the disinfectant, and the physicochemical properties of the water $[2,3,14]$. At present, the following water disinfection agents are used: chlorine gas, chlorine dioxide $\left(\mathrm{ClO}_{2}\right)$, iodine, ozone, a sodium chlorate(I) (sodium hypochlorite $-\mathrm{NaOCl}$ ) solution, and a calcium chlorate(I) (calcium hypochlorite $\left.-\mathrm{Ca}(\mathrm{OCl})_{2}\right)$ solution $[2,3,5,6]$.

Chlorination is the most popular and cheapest method of water disinfection. This consists of destroying microorganisms using pure chlorine gas or chlorine compounds. The water is typically disinfected with chlorine in the form of chlorine water or chlorine gas added directly in situations requiring the application of large doses of disinfectant [3].

In the case of chlorinating water that contains organic components, there may be chlorine derivatives formed from these compounds; also, the taste and odor of the water may deteriorate $[2,5]$. The products of reactions between halogens $(\mathrm{Cl}, \mathrm{F}$, $\mathrm{Br}, \mathrm{I})$ and hydrocarbons are halogenated hydrocarbons. Of the greatest importance among these are trihalomethanes (THMs). The most important factors affecting the formation of THMs in a water supply network are their precursors and the presence of chlorine in the water [14-18]. Increases in total THM concentrations are also affected by the formation of brominated THMs caused by bromide ions present in the water. Despite the decrease in the concentration of dissolved organic carbon in chlorinated water, the share of brominated THMs and organobromine compounds remains unaffected [15].

At water production plants, chlorine is more and more commonly being replaced with chloride dioxide. This is produced on-site from sodium chlorite and hydrochloric acid. Chloride dioxide has stronger disinfecting properties than chlorine, and its effectiveness is not dependent on the $\mathrm{pH}$ of the water. The higher technological efficiency of this disinfectant stems from the considerably higher oxidizing potential. Compared with chlorine gas, chlorine dioxide has an oxidizing rather than chlorinating effect on many compounds - when added to water, it does not create halogen side compounds. However, the application of chloride dioxide causes the formation of such by-products as chlorates(III, V). The prolonged duration of its action in water stems from the longer half-life period. The application of chlorine dioxide does not cause any increase in mutagenic or carcinogenic activity in the water. The $\mathrm{ClO}_{2}$ doses are considerably lower as compared to chlorine doses and surpass them in efficiency in a wider range of water $\mathrm{pH}$ values (up to approx. $\mathrm{pH}$ 9). Chlorine dioxide introduced into water does not impair its taste or odor, and it completely oxidizes phenols [2, 3, 5, 14, 15, 19-21]. 
The need to minimize the technical problems and hazards resulting from the use of chlorine and sodium chlorate(I) as disinfectants led to the development of the MIOX (Mixed Oxidant) technology. This consists of taking advantage of the mixture of oxidants (chlorate ion (I), chloride oxide(IV), and ozone) that were formed as a result of the electrolysis of an aqueous solution of $\mathrm{NaCl}$. This mixture inactivates the bacteria and viruses present in water more effectively than the disinfectants used separately $[2,6,22,23]$.

Ozonation is applied by passing a stream of ozonized air $\left(\mathrm{O}_{3}\right)$ through the water. Ozone is produced on the principle of electrical discharge in an alternating field of high voltage in so-called ozone generators. The pre-ozonation of water improves its color and taste and destroys any microorganisms present in the water. The advantage of ozone is that it offers the highest effectiveness of disinfection among the traditionally used oxidants. In the course of ozonation, compounds such as pesticides and surfactants are oxidized. A disadvantage of using ozone is its instability and low solubility in water. At room temperature, it decomposes to form two-atom oxygen $[3,5,6]$. The low persistence of ozone increases the hazard of secondary bacterial growth in the water supply network. Therefore, the water is subjected to chlorination or disinfection with chlorine dioxide after the ozonation process. In ozonized water, products of the reactions between the organic compounds and ozone are formed. They are characterized by significantly easier biodegradability than their reagents. For this reason, the lack of an active disinfectant in the water can lead to the growth of microorganisms in the presence of easily absorbed nutrients - the products of ozonation $[3,24]$. Ozonation can cause the formation of bromates $(\mathrm{V})$ as by-products - in the event of the presence of bromides in the water $[5,8]$. In conclusion, this process should not be the last stage of treatment [14].

Strengthened provisions concerning the quality of the water in a distribution system requires the application of new disinfection solutions. In order to improve the quality, safety, reliability, and (above all) effectiveness of the water disinfection process, many plants seek alternative solutions to chloride gas and sodium hypochlorite. One of the most modern technologies is disinfection with $65 \%$ solid calcium hypochlorite; this agent ensures a low level of chlorates and bromates due to its high purity [25]. The compounds mentioned remain on a level that ensures the fulfillment of requirements concerning the quality of drinking water that are compliant with the Regulation of the Ministry of Health [26].

\section{Materials and Methods}

The study was developed by collecting water samples after the treatment process from Krakow-based water treatment plants and from selected sampling points within the water supply network. The laboratory analysis of drinking and municipal water covered the years of 2011-2017. Samples of water after treatment were collect- 
ed at three-day intervals. Based on the results obtained, the average annual values were calculated for the seven-year period of study. The municipal water samples were collected at the designated points within the supply network every quarter on average during each year. The results of the analyses were made available by the Central Laboratory of the MPWiK S.A. in Krakow (Tab. 1).

Table 1. Methodology of testing parameters determined in 2011-2017

\begin{tabular}{||c|c|l||}
\hline Indicator & $\begin{array}{c}\text { Method } \\
\text { code }\end{array}$ & \multicolumn{1}{c|}{ Title of the standard/test procedure } \\
\hline \hline Free chlorine & 22 & $\begin{array}{l}\text { PB-NJL-W-33, issue 1 on 17.10.2011 } \\
\text { Determination of free chlorine and general chlorine in } \\
\text { accordance with PN-ISO 7393-2: 1997 }\end{array}$ \\
\hline $\begin{array}{l}\text { Chlorates(III), } \\
\text { chlorates(V) }\end{array}$ & 57 & $\begin{array}{l}\text { PN-EN ISO 10304-1: 2009 } \\
\text { Water quality. Determination of dissolved anions by ion } \\
\text { chromatography. Part 1: Determination of bromides, chlorides, } \\
\text { fluorides, nitrates, nitrites, phosphates, and sulfates }\end{array}$ \\
\hline$\Sigma$ THM & 75 & $\begin{array}{l}\text { PB-NJL-W-06, issue 1 of 18.01.2008 } \\
\text { Determination of volatile organic compounds }\end{array}$ \\
\hline \hline
\end{tabular}

Source: own study based on data [27]

The statistical analysis was performed for the selected quality indicators of municipal water: free chlorine, total THMs, and the totals of chlorates(III) and chlorates $(\mathrm{V})$. The data gathered over the seven-year period of study included purity parameters of the water collected from the distribution network during the period of January 1, 2011, and December 31, 2017. The analysis covered city zones supplied with water produced at four Krakow treatment plants (Tab. 2).

Table 2. Water sampling points in municipal water supply network in Kraków during years of 2011-2017

\begin{tabular}{|l|l||}
\hline \multicolumn{1}{|c|}{ Sampling points } & \multicolumn{1}{|c||}{ Supply area } \\
\hline \hline $\begin{array}{l}\text { ul. Zarzecze 106, al. Sosnowa 8, ul. Stawowa 179, ul. Tokarskiego 1, } \\
\text { ul. Nałkowskiego 1, ul. Łokietka 177 }\end{array}$ & WTP Rudawa \\
\hline $\begin{array}{l}\text { ul. Poronińska 7, ul. Chałubińskiego 21, ul. Stojałowskiego 1, } \\
\text { ul. Cechowa 57, ul. Babińskiego 29, ul. Spółdzielców 3, ul. Bieżanowska } \\
\text { 40, ul. Brożka 3, ul. Gronostajowa 3, ul. Kutrzeby 4, ul. Kosiarzy 1, } \\
\text { Rynek Podgórski 1, ul. Stoczniowców 7, ul. Sławka 8, ul. Sanocka 2 }\end{array}$ & WTP Raba \\
\hline ul. Kantorowicka 77, os. Złotej Jesieni 1, os. Górali 5, os. Na Skarpie 8 & WTP Dłubnia \\
\hline ul. Astronautów 5, ul. Kamedulska 70, ul. Bolesława Śmiałego 7 & WTP Bielany \\
\hline
\end{tabular}

The samples of treated water for laboratory testing were taken at points located in various Krakow districts. These were primarily public facilities such as schools, kindergartens, shops, petrol stations, and offices. 


\section{Results and Discussion}

Active chlorine responsible for the course of both oxidation and disinfection is present in chlorine water and in all of the chlorine compounds used. Therefore, it is essential to determine such a dose of chlorine that would ensure that free chlorine remains in the water after disinfection $[3,28]$. The quantity of free chlorine in potable water and household water may not exceed $0.3 \mathrm{mg} \cdot \mathrm{dm}^{-3}$ [25]. Also, a problem faced by many water treatment plants is the disappearance of chlorine at the end of the network [2, 29].

The highest concentrations of free chlorine were found in the waters produced at the Water Treatment Plant (WTP) Dłubnia; the average results ranged from 0.03 (os. Na Skarpie 8) to $0.14 \mathrm{mg} \cdot \mathrm{dm}^{-3}$ (os. Górali 5) (Fig. 1c). In addition, the maximum value of this indicator was noted on April 4, $2012\left(0.50 \mathrm{mg} \cdot \mathrm{dm}^{-3}\right)$ at ul. Babińskiego 29. The lowest concentrations of free chlorine were found in the water from the WTP Rudawa (Fig. 1a); the average results ranged from 0.02 (ul. Łokietka 177) to $0.06 \mathrm{mg} \cdot \mathrm{dm}^{-3}$ (ul. Zarzecze 106).

a)

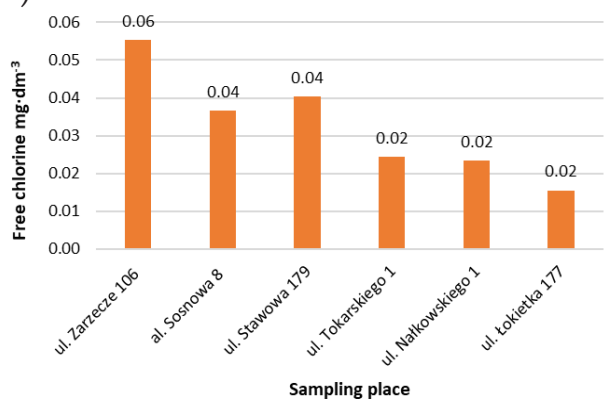

c)

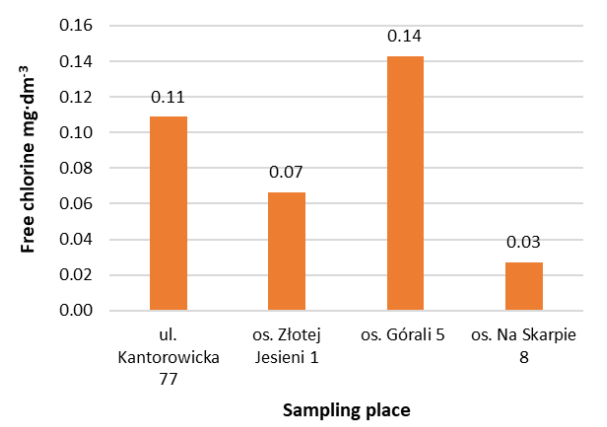

b)

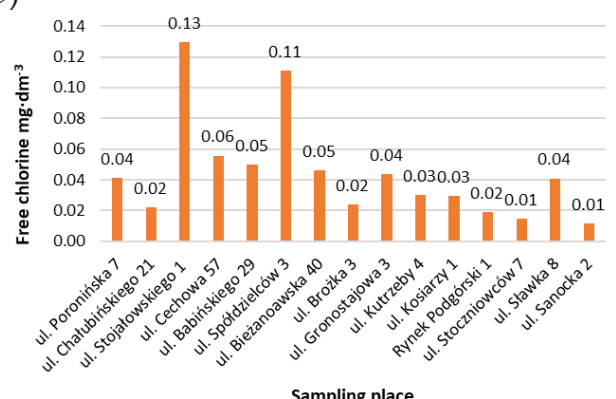

d)

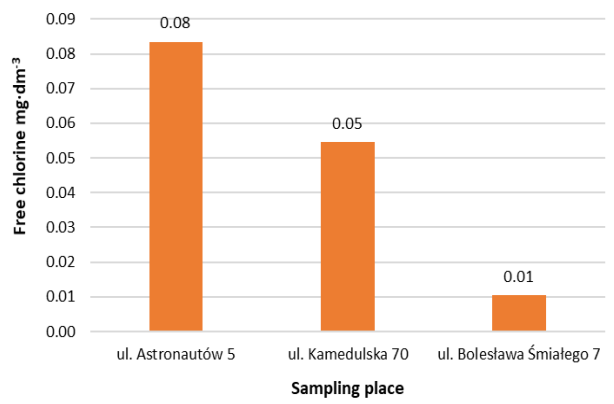

Fig. 1. Average concentrations of free chlorine in water supply network of Krakow during years of 2011-2017: a) WTP Rudawa supply zone; b) WTP Raba supply zone;

c) WTP Dłubnia supply zone; d) WTP Bielany supply zone 
It follows from the study that the free chlorine consumption in the distribution system increased along with increases in the distance from the treatment plant. This dependence was found for 18 of 29 water sampling sites. When analyzing the annual average concentrations of free chlorine in the municipal water, it was observed that the highest values were recorded in 2011 for $72 \%$ of the sites examined. During the other years, a decrease in this indicator was observed.

The highest concentrations of total THMs were found in the waters in which disinfection with chlorine gas/sodium hypochlorite was applied. These were waters delivered from WTP Raba and WTP Bielany (Fig. 2). The highest values of this indicator were recorded for the water delivered from WTP Raba. The average values during the seven-year period ranged from 18.68 (ul. Chałubińskiego 21) to $25.77 \mu \mathrm{g} \cdot \mathrm{dm}^{-3}$ (ul. Brożka 3) (Fig. 2a). In addition, the lowest values were observed in the zone supplied with drinking water from WTP Dłubnia, where the values were within a range of 0.27 (ul. Kantorowicka 77) and $8.17 \mu \mathrm{g} \cdot \mathrm{dm}^{-3}$ (os. Na Skarpie 8). In this case, the increase in the distance between the sampling place and the plant was matched by the increase in the concentration of disinfection by-products. On the other hand, this dependence was not observed in the cases of the WTP Raba and WTP Bielany delivery zones.

In the water from WTP Bielany after the treatment process, the values of this indicator ranged from 0.3 to $32.8 \mu \mathrm{g} \cdot \mathrm{dm}^{-3}$ during the years of 2007-2014. After modernization of the chlorine plant, downward trends were observed where choline gas was replaced with sodium hypochlorite produced by the electrolysis of common salt. From April 2012, concentrations of total THMs ranged between 1.5 and $9.5 \mu \mathrm{g} \cdot \mathrm{dm}^{-3}$. A sudden drop in the concentration of trihalomethanes was also observed at the sampling places in the network supplied from WTP Bielany [30].

a)

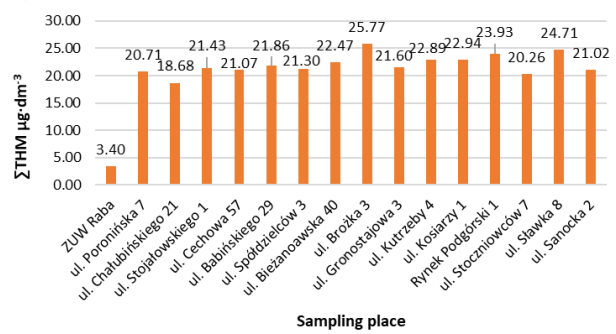

b)

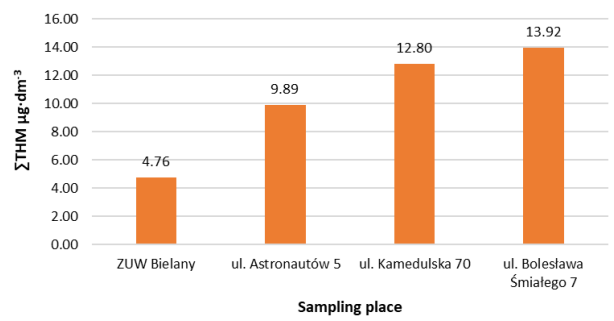

Fig. 2. Average concentrations of total THMs in water supply network of Krakow during years of 2011-2017: a) WTP Raba supply zone; b) WTP Bielany supply zone

Source: own study based on results obtained from MPWiK

The totals of chlorates(V) and chlorates(III) in the highest concentrations were present in the waters for which disinfection with chloride dioxide was applied; e.g., at the Rudawa and Dłubnia plants (Fig. 3). The average values at the sampling places 
varied from 0.03 (ul. Tokarskiego 1) to $0.43 \mathrm{mg} \cdot \mathrm{dm}^{-3}$ (ul. Zarzecze 106). The maximum value was recorded at os. Na Skarpie $8\left(0.80 \mathrm{mg} \cdot \mathrm{dm}^{-3}\right)$.

a)

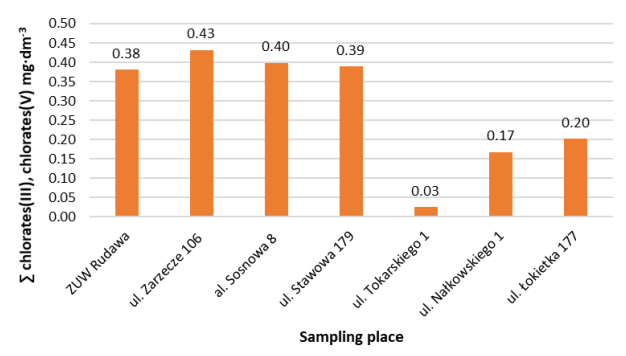

b)

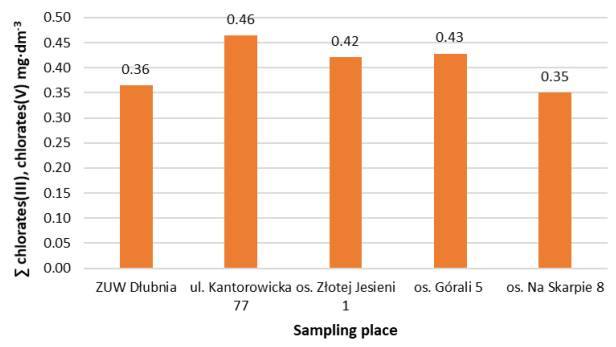

Fig. 3. Average concentrations of total chlorates(III) and chlorates(V) in water supply network of Krakow during years of 2011-2017: a) WTP Rudawa supply zone;

b) WTP Dłubnia supply zone

Source: own study based on results obtained from MPWiK

The formation of disinfection by-products in water supply networks can be reduced by removing the precursors of its formation from the water (mostly organic compounds). The greatest effectiveness for eliminating THM precursors from surface waters is achieved at filtration intakes. The removal of large quantities of organic matter is achieved through coagulation or flocculation. Slow filter processes have good effectiveness, as do filtration through charcoal beds and membrane processes. The choice of these technologies for surface water treatment considerably reduces the dose of disinfectant, reduces the potential for the formation of disinfection by-products, and does not impair the biological stability of the water [5, 31].

\section{Conclusions}

1. Concentration of free chlorine decreased along with increases in the distance from the treatment plant. This dependence was confirmed in 19 of 28 water sampling places. When analyzing the annual average concentrations of free chlorine in the municipal water, it was noted that the highest values were recorded in 2011 for $72 \%$ of the places examined. During the other years, a decrease in this indicator was observed.

2. The highest concentrations of total THMs were found in the waters in those distribution network in which disinfection with chlorine gas was applied. After modernization of the chlorine plant at WTP Bielany, a decrease was observed for this indicator in the water after the treatment process in municipal water starting in 2012. 
3. In the zones supplied with drinking water by WTP Raba and WTP Bielany, an increase in the concentration of total THMs along with an increase in distance from the plant was not observed. However, there was an increase in this indicator along with an increase in the distance from the plant in the case of the water supplied from WTP Dłubnia. This stems from the analysis that the disinfection by-products (total THMs) did not exceed permissible limits [26]

4. From the analysis of the disinfection by-products, it can be concluded that the greatest concentrations of total chlorates(III) and chlorates(V) were found in the waters that were disinfected with chloride dioxide.

\section{References}

[1] Kowal A.L. (red.): Odnowa wody. Podstawy teoretyczne procesów. Wyd. 2. Oficyna Wydawnicza Politechniki Wrocławskiej, Wrocław 1997.

[2] Gibczyńska M.: Hydrochemia. Wydawnictwo Uczelniane Zachodniopomorskiego Uniwersytetu Technologicznego w Szczecinie, Szczecin 2013.

[3] Kowal A.L., Świderska-Bróż M.: Oczyszczanie wody. Podstawy teoretyczne $i$ technologiczne, procesy $i$ urzadzenia. Wydawnictwo Naukowe PWN, Warszawa 2009.

[4] Olejnik A., Nawrocki J.: Czy woda wodociagowa musi być dezynfekowana chemicznie? Ochrona Środowiska, vol. 35, no. 4, 2013, pp. 3-8.

[5] Papciak D., Zamorska J., Kiedryńska L.: Mikrobiologia i biotechnologia w procesach oczyszczania wody. Oficyna Wydawnicza Politechniki Rzeszowskiej, Rzeszów 2011.

[6] Raczyk-Stanisławiak U., Danielak K.K.: Dezynfekcja wody. [in:] Nawrocki J. (red.), Uzdatnianie wody. Procesy fizyczne, chemiczne i biologiczne. Część 2, Wydawnictwo Naukowe PWN, Warszawa 2010, pp. 271-315.

[7] Nawrocki J.: Uboczne produkty utleniania i dezynfekcji wody - doświadczenia ostatnich 30 lat. Ochrona Środowiska, R. 27, nr 4, 2005, pp. 3-12.

[8] Richardson S.D., Thruston A.D., Caughran T.V., Chen P.H., Collette T.W., Floyd T.L., Majetich G.: Identification of new drinking water disinfection byproducts formed in the presence of bromide. Environmental Science and Technology, no. 33(19), 1999, pp. 3378-3383.

[9] Von Gunten U., Driedger A., Gallard H., Salhi E.: By-products formation during drinking water disinfection: a tool to assess disinfection efficiency? Water Research, vol. 35(8), 2001, pp. 2095-2099.

[10] Łomotowski J.: Metody i techniki optyczne w badaniach zawiesin. Instytut Badań Systemowych PAN, Warszawa 2008.

[11] Michalski R., Łyko A.: Uboczne nieorganiczne produkty dezynfekcji wody. Inżynieria i Ochrona Środowiska, t. 15, nr 4, 2012, pp. 353-364. 
[12] Sholtes K.A., Lowe K., Walters G.W., Sobsey M.D., Linden K.G., Casanova L.M.: Comparison of ultraviolet light-emitting diodes and low-pressure mercury-arc lamps for disinfection of water. Environmental Technology, vol. 37(17), 2016, pp. 2183-2188.

[13] Włodyka-Bergier A., Bergier T.: Wpływ dezynfekcji wody promieniami nadfioletowymi na potencjał tworzenia halogenowych produktów chlorowania w sieci wodociagowej. Ochrona Środowiska, vol. 35, nr 3, 2013, pp. 53-57.

[14] Hofmann O., Hoyer O., Schoenen D., Wricke B.: Dezynfekcja. [in:] Gimbel R., Jekel M., Ließfeld R. (red.) Podstawy i technologie uzdatniania wody. Tom 2, Oficyna Wydawnicza PROJPRZEMKO, Bydgoszcz 2008.

[15] Sozański M.: Procesy naturalne w rozwoju technologii uzdatniania wody (TUW). Gaz, Woda i Technika Sanitarna, nr 3, 2012, pp. 110-116.

[16] Xie Y.: Disinfection byproducts in drinking water: Formation, analysis, and control. CRC Press, 2016.

[17] Zbieć E., Dojlido J.R.: Uboczne produkty dezynfekcji wody. Ochrona Środowiska, nr 3(74), 1999, pp. 37-44.

[18] Zimoch I.: Zintegrowana metoda analizy niezawodności funkcjonowania i bezpieczeństwa systemów zaopatrzenia w wodę. Wydawnictwo Politechniki Śląskiej, Gliwice 2011.

[19] Berger M., Pacierpnik K.: Actiflo® jako sprawdzona nowoczesna technologia. ZUW Bochnia. Technologia Wody, nr 3, 2011, pp. 70-75.

[20] Jachimko B.: Chloryny w wodzie wodociagowej uzdatnianej dwutlenkiem chloru. [in:] Jędrczak A. (red.), Oczyszczanie wody - nowe trendy: woda, ścieki, odpady w środowisku: VI konferencja naukowo-techniczna, Zielona Góra, wrzesień 2003 r., Uniwersytet Zielonogórski, Zielona Góra, pp. 34-38.

[21] Lasocka-Gomuła I., Maciołek A., Kania P., Karolczak P.: Doświadczenia z wprowadzenia dwutlenku chloru do dezynfekcji w stacji oczyszczania wody w Mosinie. Ochrona Środowiska, nr 4, 2007, pp. 53-56.

[22] Son H., Cho M., Kim J., Oh B., Chung H., Yoon J.: Enhanced disinfection efficiency of mechanically mixed oxidants with free chlorine. Water Research, vol. 39(4), 2005, pp. 721-727.

[23] Venczel L.V., Arrowood M., Hurd M., Sobsey M.D.: Inactivation of Cryptosporidium paroum oocysts and Clostridium perfringens spores by a mixed-oxidant disinfectant and by free chlorine. Applied and Environmental Microbiology, vol. 63(4), 1997, pp. 1598-1601.

[24] Jyoti K.K., Pandit A.B.: Ozone and cavitation for water disinfection. Biochemical Engineering Journal, vol. 18, no. 1, 2004, pp. 9-19.

[25] Konieczna M.: Podchloryn wapnia - skuteczny, wygodny i łatwy w użyciu środek do dezynfekcji wody. Technologia Wody, nr 5(13), 2011, pp. 46-47.

[26] Rozporzadzenie Ministra Zdrowia z dnia 7 grudnia 2017 r. w sprawie jakości wody przeznaczonej do spożycia przez ludzi. Dz.U. 2017, poz. 2294. 
[27] Centralne Laboratorium MPWIK S.A.: Wyniki analiz laboratoryjnych wskaźników jakości wody surowej i pitnej w ZUW: Bielany, Raba, Dłubnia, Rudawa wykonane w Centralnym Laboratorium w latach 2007-2017, Kraków 2019.

[28] Zheng M., He C., He Q.: Fate of free chlorine in drinking water during distribution in premise plumbing. Ecotoxicology, vol. 24(10), 2015, pp. 2151-2155.

[29] Januszewska A., Bojanowska I., Ryłko E.: Wpływ zmiany sposobu dezynfekcji wody przeznaczonej do spożycia na jej jakość. Technologia Wody, nr 4(12), 2011, pp. 14-17.

[30] Adamczyk W., Jachimowski A.: Wpływ modernizacji chlorowni na jakość wody uzdatnionej. Gaz, Woda i Technika Sanitarna, nr 2, 2016, pp. 58-61. DOI: 10.15199/17.2016.2.4.

[31] Łomotowski J.: Przyczyny zmian jakości wody w systemach wodociagowych. Instytut Badań Systemowych PAN, Warszawa 2007.

\section{Wpływ różnych metod dezynfekcji na jakość wody wodociągowej}

Streszczenie: W artykule określono wpływ stosowania silnych utleniaczy w technologii uzdatniania wody na powstawanie ubocznych produktów dezynfekcji. Przedmiotem badań były wody pobierane z czterech zakładów uzdatniania wody Miejskiego Przedsiębiorstwa Wodociągów i Kanalizacji w Krakowie oraz z wybranych punktów sieci wodociągowej. Analizie poddano wybrane wskaźniki jakości wody (chlor wolny, sumę chloranów(III) i chloranów(V) oraz sumę trihalometanów) po procesie uzdatniania w latach 2011-2017. Z przeprowadzonych badań wynika, że stężenie chloru wolnego w sieci wodociągowej malało w miarę wzrostu odległości od zakładu uzdatniania. Zależność tę stwierdzono w 19 z 28 punktów poboru wody. Analizując średnioroczne stężenia chloru wolnego w wodzie wodociągowej, zauważono, że najwyższe wartości w badanych punktach występowały w $2011 \mathrm{r}$. W pozostałych latach obserwowano spadek tego wskaźnika. Z przeprowadzonej analizy wynika, że produkty uboczne dezynfekcji wody nie przekraczały dopuszczalnych norm.

Słowa

kluczowe: dezynfekcja wody, jakość wody, woda pitna, sieć wodociągowa 